\title{
LABORATORY 3.0: MANUFACTURING TECHNOLOGIES LABORATORY VIRTUALIZATION WITH A STUDENT-CENTRED METHODOLOGY
}

\author{
Albert Fabregat-Sanjuan ${ }^{1}$ D, Rosa Pàmies-Vilà ${ }^{(D}$, Francesc Ferrando Piera ${ }^{1}$, \\ Silvia De la Flor López ${ }^{1}$ iD \\ ${ }^{1}$ Universitat Rovira i Virgili (Spain) \\ ${ }^{2}$ Universitat Politècnica de Catalunya (Spain) \\ a.fabregat@urv.cat, rosa.pamies@upc.edu, f.ferrando@urv.cat, silvia.delaflor@urv.cat
}

Received November 2016

Accepted February 2017

\section{Abstract}

This paper presents a blended-learning strategy for improving the teaching method applied in the laboratory subject Manufacturing Technologies. The teaching method has been changed from a predominantly teacher-centred to an active learning system with a student-centred focus and e-learning activities. In face-to-face classes, a game-based learning platform has been used. This methodology ensured engaging classes at the same time that provided a useful live feedback for students and teachers. The virtualization of the laboratory was achieved by two different e-learning activities, selfassessment tasks and video clips. These e-learning tools have been used not only to improve the students' learning but also to enhance their motivation. Academic results show a significant improvement after the new blended learning method is applied. Moreover, a student satisfaction survey shows the positive impact of the methodology on the students' engagement and motivation.

Keywords - Blended learning, Self-assessment, Video clip, Engineering, Student-centred, Game-based learning. 


\section{Introduction}

The laboratory subjects that are part of the Mechanical Engineering bachelor's degree from the Rovira i Virgili University are mainly focused on teaching the industrial procedures and experimental techniques through a series of theoretical and practical sessions (laboratory). These subjects are merged with the corresponding theoretical subjects but have their own assessment, management and organizational structures. Even so, laboratory subjects are not positively rated by students because they require considerable effort to pass. Students are not familiar with laboratory procedures and they have to carry out previous tasks beforehand if they want to take full advantage of each practical session. This preparation consists of handing in exercises before each session and reading technical manuals about the equipment they will be required to use in the laboratory. Students are assessed on a variety of things but of particular importance is the final oral exam with a weight of $40 \%$ of the total mark. This oral exam is considered as a major challenge by students who do not feel prepared to orally explain their knowledge of each practical session. All this helps to understand why some students do not fully engage with the subject and why the success rate is lower and the dropout rate higher than expected.

From the experience of teaching this particular laboratory subject, teachers got the feeling that students were not satisfactorily involved with the subject for various reasons. The subject is an extremely specific one, because it requires not only an overall understanding of mechanical engineering but also a specific knowledge of industrial manufacturing procedures that students are not familiar with. The problems that hindered the acquisition of the learning outcomes were essentially attributed to the methodology, which was exclusively based in face-to-face learning. This methodology did not motivate the students neither they felt engaged to the subject. Other studies have identified lack of motivation as a possible reason for lower academic results and higher dropout rates (Fernández Rico, Fernández Fernández, Álvarez Suárez \& Martínez Camblor, 2007; Galán Delgado \& Cabrera Guillén, 2002). In previous years, this lack of motivation was noticed through interviews with students who had dropped out the subject. In these interviews, students manifested a lack of engagement due to the difficulties for following the subject from one practical session to the other and for remembering the procedures involved in each practical session for the final oral exam.

Because of the aforementioned before, the objective of the new learning system was to create a learning methodology that engage and motivate students to the subject in order to improve the academic results. The option chosen was a blended learning strategy combining the face-to-face 
sessions with new e-learning tools. These new e-learning tools have the objective of getting the students engaged to the subject via attractive activities that students will feel as positive. Some of these new e-learning activities would generate an individual weekly mark for each student and help them to remember the practical sessions for the oral exam. A change was also made to the evaluation method, introducing different exam methodologies and giving more weight to individual marks.

The first improvements to a laboratory subject on the Mechanical Engineering Bachelor Degree took place in the Strength of Materials laboratory subject taught in the second semester of the second year (De la Flor, Ferrando \& Fabregat-Sanjuan, 2016). The enhancement was based on a blended learning strategy similar to this research. Due to the confirmed advantages of the blended learning strategy on laboratory subjects, in this paper we make improvements to the learning process in the laboratory subject Manufacturing Technologies (LMT). LMT is taught in the first semester of the third year of the Mechanical Engineering Bachelor Degree. The blended learning strategy has been based in the use of e-learning activities (self-assessment tasks and video clips), the improvement of the students' material (technical documents and reports) and the implementation of the game-based application (Kahoot!) in the face-to-face theoretical sessions. The combination of these improvements makes the change from a traditional laboratory subject to an engaging student-centred laboratory subject.

Other courses with similar strategies conclude that a blended learning strategy with greater participation from the students led to better academic results (Liang, 2010; Smith, 2013; Zhang, Zhou, Briggs \& Nunamaker, 2006). Nevertheless, we also considered the possible drawbacks of e-learning activities so that we could successfully implement our blended learning strategy (Govindasamy, 2001; Kaur, 2013; Manca \& Ranieri, 2013; Welsh, Wanberg, Brown \& Simmering, 2003). The main potential drawback of our system was that we would have to create an elearning environment that was attractive enough to encourage students to take part and not prompt a negative reaction to the extra work of all the e-learning activities on top of the standard face-to-face activities. Because of that, the blended learning strategy should create new e-learning tools that will help the students to engage with the subject without overwhelming them with a lot of extra work.

Finally, in order to verify the new learning methodology and evaluate the project, a variety of analytical techniques was applied. These techniques were a comparison with the academic results 
of previous years, a student satisfaction survey on the novel methodology and a statistical calculation of the correlation between the marks obtained in all the items assessed.

\section{Design/methodology/approach}

The study involved the students from the 2015/16 LMT course. The group was made up of 62 students with an average age of 20, only 8 of whom were women. Students complete 60 face-toface teaching hours in one semester to acquire a practical understanding of the main concepts of manufacturing technologies as applied to engineering systems.

The implementation of the blended learning strategy was related to the characteristics and contents of the laboratory subject. The manufacturing technologies laboratory contents are divided into five modules, and each module can be made up of several practical sessions. Table 1 lists the practical sessions involved into the different modules.

\begin{tabular}{|l|c|l|}
\hline \multicolumn{1}{|c|}{ Module } & $\begin{array}{c}\text { Practical } \\
\text { Session }\end{array}$ & \multicolumn{1}{c|}{ Title } \\
\hline \multirow{2}{*}{$\begin{array}{l}\text { Module I - } \\
\text { Metrology }\end{array}$} & P1 & Introduction to metrology \\
\cline { 2 - 3 } & P2 & Metrology applied to gears and thermal expansion coefficient \\
\cline { 2 - 3 } & P3 & Metrology applied to threads and statistical process control methods \\
\hline \multirow{2}{*}{$\begin{array}{l}\text { Module II - } \\
\text { Machining }\end{array}$} & P5 & Uncertainty of measure and roughness \\
\cline { 2 - 4 } & P6 & Masic machining workshop operations \\
\cline { 2 - 3 } $\begin{array}{l}\text { Module III - Polymer } \\
\text { Processing }\end{array}$ & P7 & Computerized numerical control \\
\hline $\begin{array}{l}\text { Module IV - Metal } \\
\text { Forming }\end{array}$ & P9 & $\begin{array}{l}\text { Plastic deformation manufacturing (rolling, drawing, bending, profile } \\
\text { curving, cutting, stamping, punching) }\end{array}$ \\
\hline $\begin{array}{l}\text { Module V - Welding } \\
\text { and Cutting }\end{array}$ & P10 & $\begin{array}{l}\text { Welding (oxy-fuel, SMAW, MIG/MAG, TIG, RSW) and cutting (plasma } \\
\text { and oxy-fuel) }\end{array}$ \\
\hline
\end{tabular}

Table 1. Practical sessions involved into the different modules

Each session involves a theoretical session of one hour in which the main concepts are taught and a three-hour practical session wherein students work in groups to complete the necessary procedures in each session. A laboratory report has to be handed in at the end of each laboratory session. This report is the guide for the students to follow the steps needed to obtain the experimental results. Once the experimental data is obtained, the conclusions drawn from the results have to be added before handing in the report. Since the report has to be completed 
within the three-hour laboratory session, students are required to share out the work and then bring it all together to arrive at the conclusions.

\subsection{The blended-learning strategy}

The new blended-learning strategy is based on the use of different teaching tools that combine elearning technologies with face-to-face methods. This type of strategy is characterized by the convergence of traditional face-to-face systems and online distance learning systems, thereby forming integrated and complementary environments (Bonk \& Graham, 2012; Gámiz Sánchez, Montes Soldado \& Pérez López, 2014; Güzer \& Caner, 2014; Osorio Gómez, 2010; Smith, 2013). Online methodologies in general and blended-learning models in particular have been well received by lecturers and students because of their usefulness, the flexibility they allow and the greater degree of student involvement and participation they permit (Sancho-Vinuesa \& Escudero Viladoms, 2012; Seluakumaran, Jusof, Ismail \& Husain, 2011). Implementing blended learning strategies has also been found to improve academic performance (Cabero Almenara, Llorente Cejudo \& Morales Lozano, 2013; Garrison \& Vaughan, 2007).

In all practical sessions, a set of educational tools has been applied to guide the students through the practical sessions. Each practical session has a section in the Moodle platform with:

- Technical information: links to technical information, equipment datasheets, manufacturing procedures and standards to follow for each practical session.

- A student's guide/report: this guide is what students have to fill in with their experimental results and conclusions to become the final report to hand in at the end of the practical session.

- The link to the YouTube video: with the main parts of the practical session and subtitles that highlight the important concepts and procedures.

- The link to the previous self-assessment test: this test is intended to prepare the practical session and it must be done between the theoretical session and the practical session.

- The link to the subsequent self-assessment test: this test is intended to evaluate the knowledge acquired in the practical session and to prepare the partial exams. It must be done between the practical session and the partial exam. 
Apart from the self-assessment tasks to complete by the students outside the classroom, the Kahoot! game-based platform is used to raise questions during the theoretical session and evaluate in live the answers from the students. The Kahoot! application has been widely accepted by the students because it has an attractive interface and students are attracted by the way they use their smartphones to answer the questions raised. Recently, a study (Wang, 2015) has pointed out that Kahoot! has no wear out effect and can be used repeatedly (one session per week during five months) without losing the students' perception in relation to user-friendliness, engagement, motivation, classroom dynamics, concentration and perceived learning. The idea of using this tool was to transform the standard theoretical classes into attractive classes that imply a competition between students. This competition is based in the way Kahoot! shows the results. The fastest five students to choose the correct answer (the application not only takes into account the correct answers but also the time to answer) are displayed at the classroom screen after each question. At the same time, students and the teacher have an idea of the knowledge acquired on the theoretical session. Other studies have analysed the advantages of using gamebased platforms for learning purposes (Ebner \& Holzinger, 2007; Kiili, 2005; Sharples, 2000). Trying to avoid putting too much pressure on the students, Kahoot! tests were not considered for assessment. Moreover, Kahoot! application does not allow using a correct student identification method (the users write themselves their names at the beginning of the test) in order to be used for assessment.

The use of the self-assessment tests to be answered via the Moodle platform (Fabregat-Sanjuan, 2015a) were based on several studies that have related the use of a learning strategy based on self-assessment activities to improvements in student performance (Boud, 2003; Ćukušić, Garača \& Jadrić, 2014; Snodin, 2013), so they would seem to be an excellent aid for our subject. The use of the video clips accessible via YouTube (Fabregat-Sanjuan, 2015b), can be effective in improving levels of student engagement in the learning process, improving the levels of retention and competence acquisition (Manca \& Ranieri, 2013; Rama, 2014).

The objective was to introduce this set of e-learning tools in combination with face-to-face practical training (essential in this kind of subject) to improve learning outcomes and motivate students. This project therefore focuses on the accurate design, development, implementation and evaluation of the new teaching methodology for practical training aided by e-learning environments. 
The assessment system for this subject focus on both the content and the acquisition of transversal competences. For this reason, the evaluation method is made up of different assessment items. Table 2 lists the evaluation items and shows the weight of each one for both the old and the new methods.

\begin{tabular}{|c|c|c|c|}
\hline Learning strategy & Individual / Group & Item & Weight (\%) \\
\hline \multirow{3}{*}{ Traditional / Old method } & Group & Reports (PS) & 30 \\
\hline & \multirow{2}{*}{ Individual } & Partial Oral Exam (PS1-PS5) & 30 \\
\hline & & Final Oral Exam (PS1-PS10) & 40 \\
\hline \multirow{6}{*}{$\begin{array}{c}\text { Blended learning strategy / } \\
\text { New method }\end{array}$} & Group & Reports (PS) & 20 \\
\hline & \multirow{5}{*}{ Individual } & Previous self-assessment tests & 5 \\
\hline & & Subsequent self-assessment tests & 5 \\
\hline & & Partial Test Exam (PS1-PS5) & 15 \\
\hline & & Partial Test Exam (PS6-PS10) & 15 \\
\hline & & Final Oral Exam $(\mathrm{OE})$ & 40 \\
\hline
\end{tabular}

Table 2. Evaluation items and weight

As Table 2 shows, with the blended learning strategy there are new items (self-assessment tasks and written partial test exams) that did not exist before. Consequently, the weight of the reports and oral exams has been reduced in comparison with the old method. With the new assessment method students undergo more continuous evaluation, because they are marked each week on each self-assessment task. Moreover, a written partial test exam has been added. One of the best evaluation techniques used in practical training subjects is the oral exam, because of that, the oral exam is still an important part of the new assessment method, but instead of two, only the final exam is an oral. Here the student gives a five-minute presentation on one of the practical sessions, chosen at random, and then answers questions from the teaching staff for another five minutes. The weight of individual assessment has increased, which implies higher individual responsibility. Nevertheless, $20 \%$ of the total mark still comes from reports done in groups, so students are forced to practise their social skills in order to work with others 


\subsubsection{E-learning materials}

In this section, we explain the e-learning materials used in the blended learning strategy. They consist of video clips with detailed instructions regarding the development of each practical session, the self-assessment tasks on the educational Moodle platform that have to be done before and after each practical session and the use of the Kahoot! game-based application in theoretical classes. An example of the learning material can be seen in Figures 1, 2 and 3.

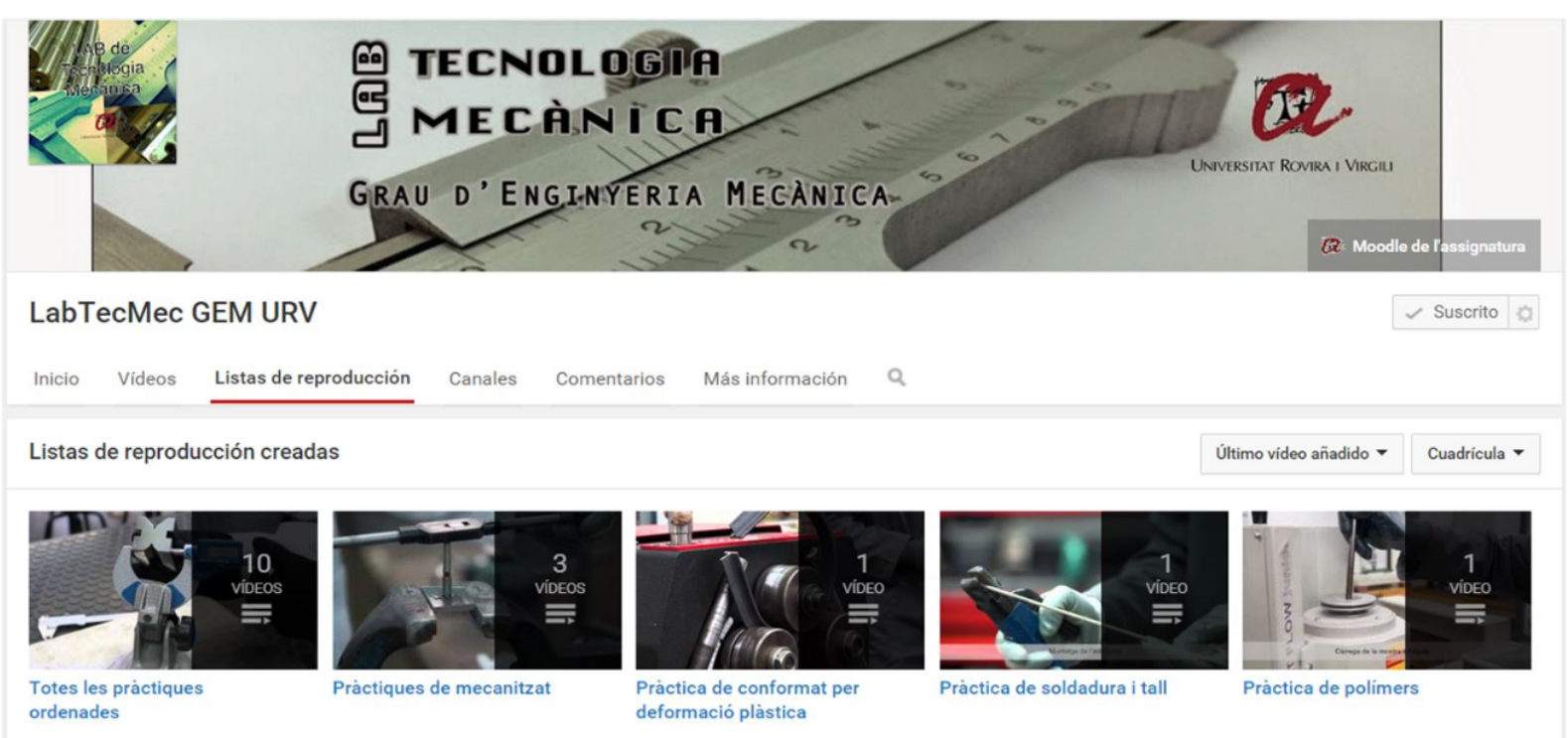

Figure 1. YouTube subject page with the videos for each practical session

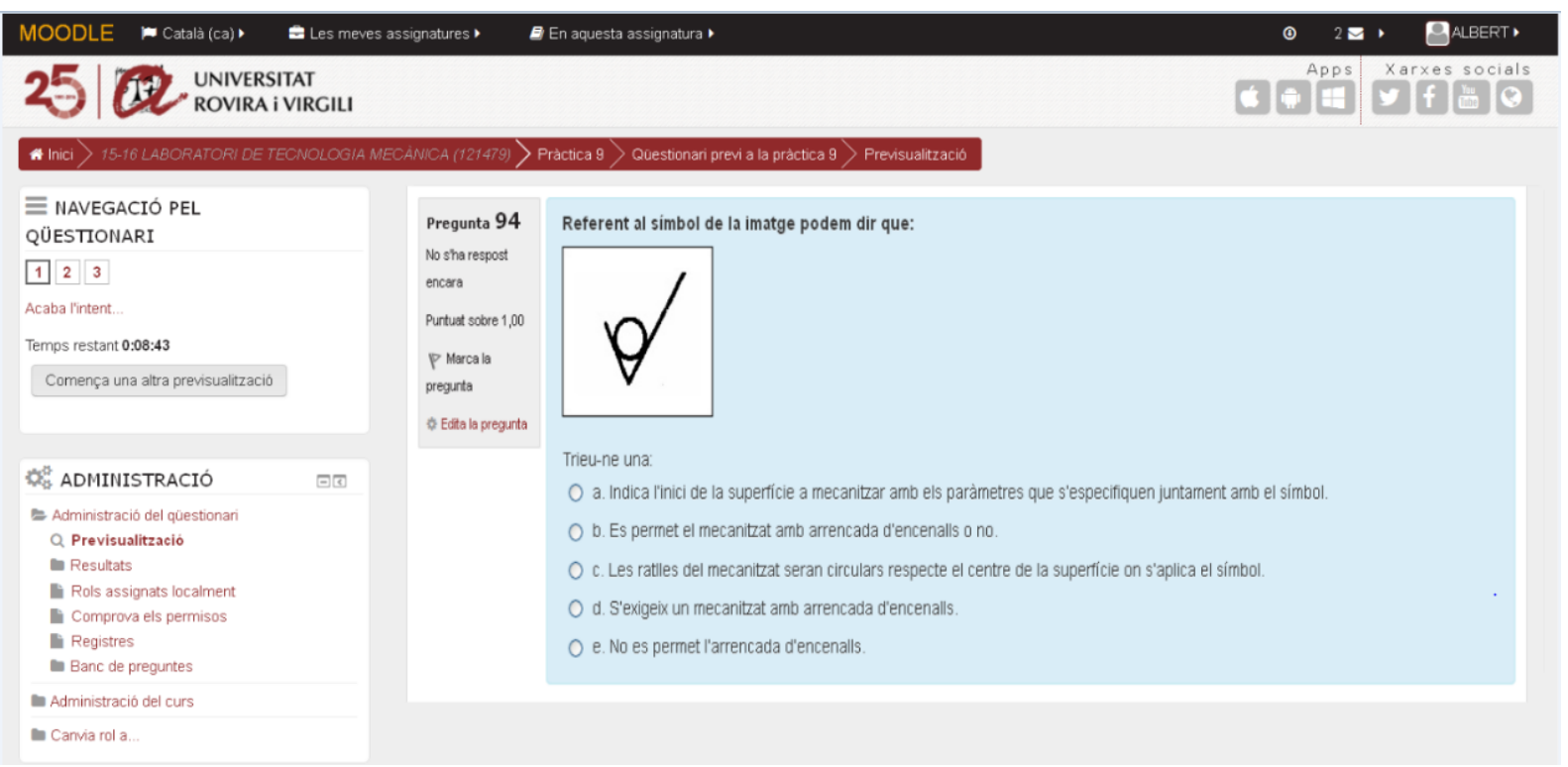

Figure 2. Educational platform (Moodle) with an example of the self-assessment tasks 


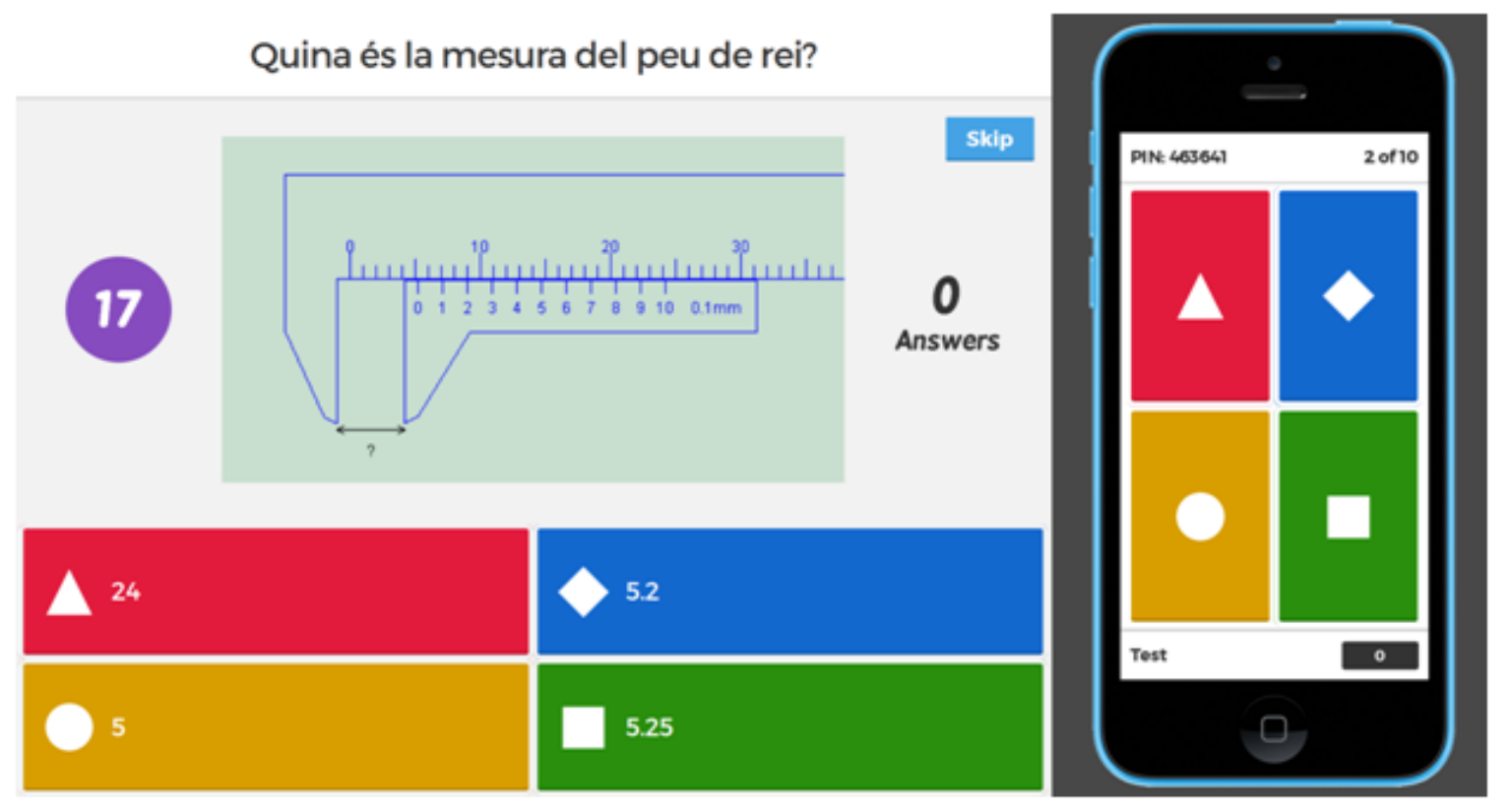

Figure 3. Example of a question raised to the students in the theoretical classes via the Kahoot! application

The video clips mainly consist of a summary of the recordings made in real laboratory practical sessions. They also include some still pictures that give details of the equipment used and subtitles that give the main points and procedures (technical characteristics and regulations of the laboratory equipment).

The main idea is that students use the videos to prepare the practical sessions in advance (they will be shown what will be done) and to prepare the exams (they will be able to review the main points of each practical session). As Figure 1 shows, video clips summarizing the main idea behind each practical session were uploaded to a YouTube channel (LabTecMec GEM URV). Since students are very familiar with using YouTube, videos are seen as a positive way for making learning interesting and exciting for them. The YouTube platform is also positive because it is easy to use and its video configuration works on PCs, tablets and smartphones. Because students do a different practical session each week, videos are a useful tool for reminding them what procedures were done in each session. In addition, the subtitles on each video clip cover the main points of each practical session. Videos of each laboratory session also help the students to remember the more important parts of each session. They can also be watched as many times as the students need, and so the learning process is adapted to each student. 
Self-assessment activities are exercises made up of different kinds of questions (multiple choice, numeric, essay, true/false and matching) to be done on the Moodle platform. Students are used to Moodle and have shown a better attitude towards doing activities there as opposed to the traditional type of exercise (Boud, 2003; Gámiz Sánchez et al., 2014; White, 2007). They therefore engage with the self-assessment tasks and become motivated towards the subject. The self-assessment tasks are divided into exercises to be done before and after each laboratory session. The self-assessment tasks to be done before the session force the students to study beforehand, thereby improving their learning and achieving better marks in the practical sessions. The self-assessment tasks to be done after the practical session are useful for finding out what the students have learned on the session and also serve as a guide when preparing for the final oral exam. The questions are ordered randomly and there are many more than those used on each student, and therefore each time a student attempts a task, the questions are different. This forces the students to learn the theoretical concept and procedures carried out in each practical session before they can pass the self-assessment task. Students can attempt each test twice. We decided that self-assessment tests should only be answered twice because we did not want students to spend too much time on these tasks. If they make only one attempt, the mark obtained is the mark of the test; if they make two attempts the mark is the average.

Kahoot! application is a game based strategy used in the theoretical classes to check in live what the level of the knowledge is. It consists of multiple choice questions - as a quiz, discussion or survey - which can be created by the teacher beforehand and then asked in live in the classroom, to an unlimited number of students. Teacher can also specify the time required to answer each question.

When the application is initiated, a unique identification number (UIN) is generated by the system. Using a smartphone, tablet or PC, students go to the website www.kahoot.it and they log in with the UIN displayed in the classroom and enter their nickname. Students are required to write their real name because once the quiz is finished the teacher can download the results of all the students. When all students' nicknames appear in the screen, the teacher clicks the Start button to begin the questionnaire.

The questions are projected on the classroom screen. Four multiple-choice answers are displayed for each question, where each answer corresponds to a distinctive color and shape that students can also see on its device. A number of points is awarded to each student for every question 
answered correctly. The obtained points depend on the time the student takes to answer the question.

Students see their current score and their ranking in the class on their own screen. Moreover, the five highest scores are displayed on the classroom screen after each question to encourage a healthy competition among students.

The experience using this game based application is extremely positive and has changed the theoretical session's methodology. Before using the Kahoot! the theoretical sessions were mainly master classes were students did not participate at all. Because of that, students had a passive attitude that worsened their learning. Moreover, this passive role did not imply any preparation before the session. In contrast, after the Kahoot! implementation, students have to prepare in advance the theoretical sessions because they know in advance that they will have to prove which their level of knowledge is. The methodology is also based in a master class but with a live feedback from the students that guide teachers to focus the misunderstood concepts and maintain a high level of concentration in students. In order to minimize the time spent answering the Kahoot! quiz and to create a dynamic atmosphere, questions has a limited time response between 10 and 20 seconds and quizzes have a maximum of 10 questions. The higher concentration level is motivated by the competition between students and the way Kahoot! shows the results. The fastest five students to choose the correct answer are displayed at the classroom screen after each question. It creates a competition between students that fosters the learning process. After each quiz the Kahoot! results are analyzed by teachers but are not considered as an assessment item. We consider a drawback that students put themselves their names because it is not safe enough for taking the marks of the Kahoot! quizzes as an assessment item.

\section{Results and discussion}

In this section, we analyse the results of implementing the new learning strategies. The main results consist of feedback from the students, the academic results comparison with previous years and the statistical correlation between the marks obtained in the different assessment items.

At the end of the semester, students completed a survey to evaluate the new learning strategies. The aim of this survey was to evaluate the satisfaction of the students with the new methodology. The student satisfaction survey was anonymously answered on Moodle by all the students enrolled to the subject. The most important results are shown in Figure 4. 


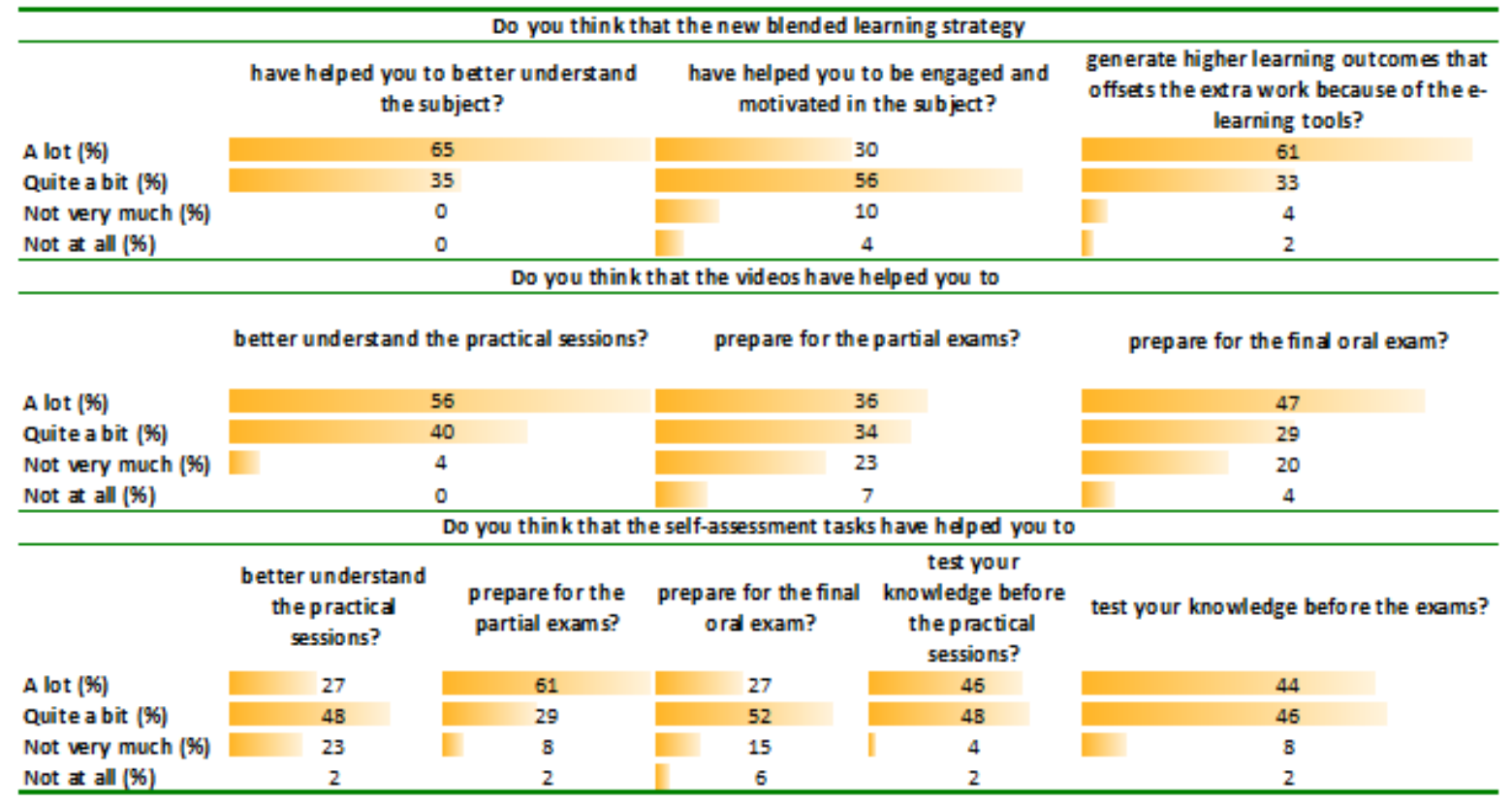

Figure 4. Student survey results regarding the satisfaction of the new blended learning methodology and specifically for the video clips and self-assessment tests

The students' survey showed a very positive feedback with the new student centred strategy. Students have shown to be more motivated. The results show that $100 \%$ of the students confirm the new methodology has helped them in their learning process. The $86 \%$ of the students are more motivated and $94 \%$ of the students think that the higher learning outcome offsets the extra work because of the e-learning tools. Regarding the students' perception of the video clips, 96\% of those surveyed believed that the videos helped them a lot or quite a bit to better understand the practical sessions, $76 \%$ thought they helped a lot or quite a bit to prepare for the final oral exam and $70 \%$ of students thought the videos helped them a lot or quite a bit to prepare for the partial exams. These results confirm that videos are considered as very useful for students and especially for preparing the practical sessions and the oral exam. If we analyse how the students perceive the self-assessment tasks, $90 \%$ of the students thought they helped a lot or quite a bit to prepare for the partial exam, $79 \%$ thought they helped a lot or quite a bit to prepare for the final oral exam and $75 \%$ thought they helped a lot or quite a bit to better understand the practical sessions. These results indicates that self-assessment tasks are considered especially useful for preparing the exams and practical sessions. Moreover, the results also showed that students considered very useful the self-assessment tests for knowing which was their level of knowledge before the exams and the practical sessions. 
All this new learning process was aimed at improving academic results, so another evaluation of the implementation of the new methodology was obtained from the academic results. Figure 5 shows the comparison between the academic results of three academic years. The course 2013/14 was the last year taught with the traditional system and 2014/15 was the first year to introduce the blended learning methodology but not all the material was ready and Kahoot! was not used. Finally, course 2015/16 is the course where all the blended learning methodology explained in this investigation was used from the beginning of the course. The comparison from Figure 5 shows an increase of 15 points in the success rate and a reduction of 9 points in the dropout rate between the course 2013/14 and the course 2015/16. These results confirm the use of the new methodology. In order to validate the academic results, the access marks to the Mechanical Engineering bachelor's degree from the groups analysed were compared (Access mark 2013-2014: 5.955, Access mark 2012-2013: 6.5, Access mark 2011-2012: 6.546). The minor differences in the access marks between the groups analysed confirm the results from Figure 5 and even enhance the academic results because the reduction in the access mark in course 20132014 does not affect the academic results (students from course 2015-16). It is important to highlight that more important than increasing the success rate, which has an important historical variability, is the decrease of the dropout rate. The dropout rate was historically high in the laboratory subjects because of the fear of the students to the final oral exam. The reduction of the dropout rate means that the new learning methodology encourages the students them to cope with the final oral exam. Even though the results of 2015/16 are great, the authors hope to maintain or increase the success rate and lower the dropout rate to zero in the coming years by using the methodology presented on this paper. 


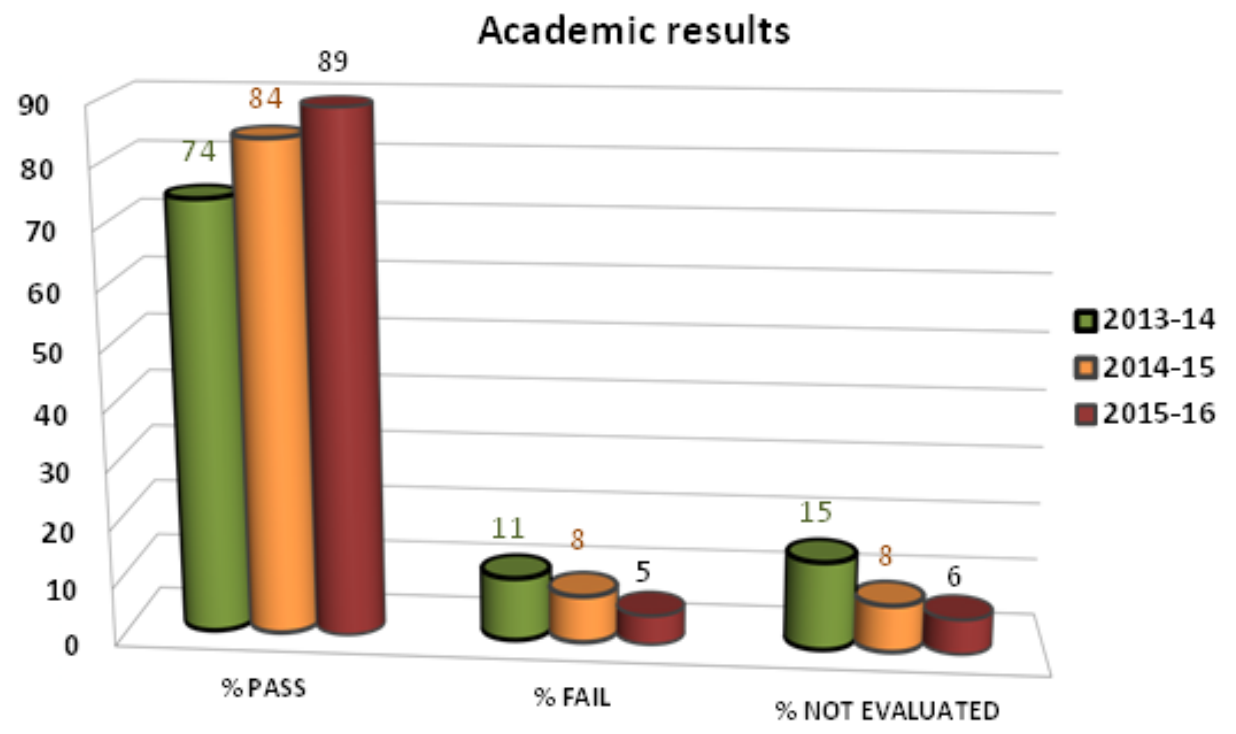

Figure 5. Academic results comparison between the last year using the traditional learning strategy (2013/14), the first year of the blended learning methodology (2014/15) and the year (2015/16) with the complete development of the student-centred learning strategy

To evaluate the relation between the different assessment items, we calculated the Pearson correlation coefficients between the students' marks on each assessment item calculated together with their standard error and the hypothesis test. The hypothesis test was calculated with $\mathrm{n}=62$, a significance level of $99 \%$ ( $\mathrm{p}$-value of 0.01 ) and the corresponding t-value of 2.66. Table 3 shows the statistical calculations for the different assessment items.

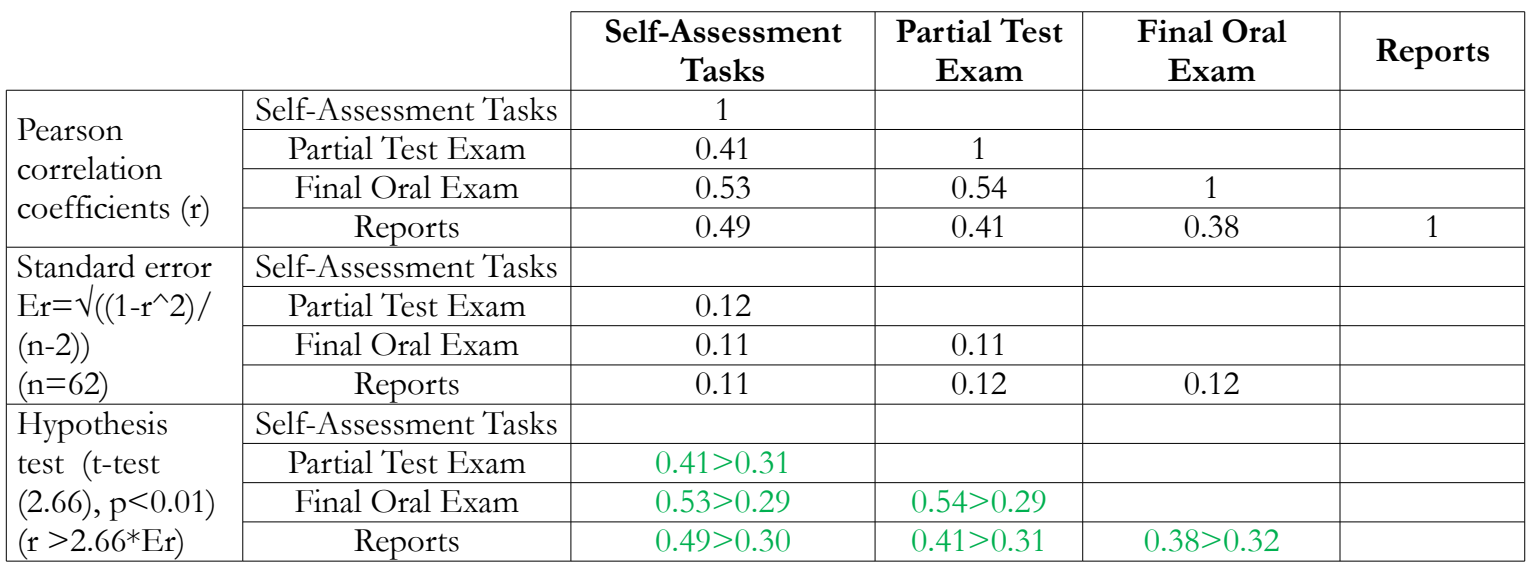

Table 3. Correlation coefficient calculations for the different assessment items

The results from statistical calculations for the different assessment items show that all correlation values between the different assessment items are higher enough to pass the 
hypothesis test. Specifically, it is important to highlight that the correlation between the selfassessment tasks and the rest of the items are statistically significant after the hypothesis test. These results confirm that the self-assessment tasks are a good guide for students to find out their level of knowledge before the exams. They also confirm that those students with higher marks on the self-assessment tasks are also those with higher marks in the exams, which indicates that self-assessment tasks are useful when it comes to preparing for the partial test exam and the final oral exam. The statistically significant correlation value between the partial test exam and the final oral exam $(0.54>0.29)$ is also important because in the new learning strategy, the partial exam was changed from an oral to a written one. This result justifies the change and confirms the relation between the marks obtained in the written partial exams and the final oral exam. The lowest correlation value (0.38) is found between the final oral exam and the reports. Even though this value is higher enough to pass the hypothesis test, the result should not be strictly taken into consideration because reports are made in groups and the rest of the tasks are individual.

\section{Conclusions}

The present pilot study shows that the blended learning methodology implemented with a student-centred focus, improves the teaching/learning process. The results obtained reveal that elearning activities done out of class (self-assessment tests and video clips) and e-learning activities done in class (Kahoot!) support and complement face-to-face laboratory classes. The e-learning activities included in the blended learning have been useful for the students. Self-assessment tasks demand constant attention every week that keeps the students engaged in the subject. Moreover, they are also a useful tool for training and provide feedback, which help students for continuous improvement. Likewise, videos are attractive tools for keeping students engaged with the subject and helping them to become familiar with the procedures involved in the laboratory. Videos have also been essential to decrease the dropout rate because they help to prepare for the final oral exam. Videos are a useful tool to summarize the oral exposition, as well as for preparing students for the short questions that have to be answered directly after the oral exposition. The implementation of the Kahoot! game-based application in the face-to-face theoretical sessions has improved the learning process. Theoretical sessions have changed from master classes were students had a passive attitude to a master class were students have an active attitude and teachers have live feedback from the students that guide them to focus the misunderstood concepts and maintain a high level of concentration in students. The application also increases the motivation of the students and helps them to be actively engaged in class. 
Improving the learning process of the laboratory subject Manufacturing Technologies using a blended learning strategy has led to a noticeable improvement in the quality of teaching and learning on the course. This improvement is backed up by greater academic results (not only with a higher rate of success but also with a reduction in the dropout rate) and an increase in student motivation and satisfaction. Students show a positive attitude and extra motivation with the new methodology despite the fact that they are forced to carry out e-learning activities out of class and recognize they have to work more than with traditional learning strategies.

Besides the conclusions found, some limitations of this research must be considered. The main limitations of this research are the limited sample (although the methodology has been contrasted with two subjects during two academic courses, it would be interesting to apply this methodology to other laboratory subjects), the context of learning analyzed (it could be interesting to apply the same learning methodology to other engineering degrees with laboratory subjects). Because of that, the authors consider that this research should continue with more studies to fully support the evidences and the conclusions found.

\section{Acknowledgments}

We thank the Scientific Committee from CIDUI 2016 for considering the paper presented at the conference (Fabregat-Sanjuan, Pàmies-Vilà, Ferrando Piera \& De la Flor, 2016) as one of the proposed contributions to be part of this publication in the JOTSE journal.

\section{References}

Bonk, C.J., \& Graham, C.R. (2012). The Handbook of Blended Learning: Global Perspectives, Local Designs. San Francisco CA: John Wiley \& Sons. Retrieved from: https://books.google.com/books? $\underline{\mathrm{id}=2 \mathrm{u} 2 \mathrm{~T} \times \mathrm{K} 06 \mathrm{PwUC} \text { epgis }=1}$

Boud, D. (2003). Enhancing Learning through Self Assessment (Routledge Falmer, Ed.). London and New York: Taylor \& Francis Group.

Cabero Almenara, J., Llorente Cejudo, M. del C., \& Morales Lozano, J.A. (2013). Contributions to e-Learning from a Best Practices Study at Andalusian Universities. RUSC. Universities and Knowledge Society Journal, 10(1), 45-60; 226-239. https://doi.org/10.7238/rusc.v10i1.1159 
Ćukušić, M., Garača, Ž., \& Jadrić, M. (2014). Online self-assessment and students’ success in higher education institutions. Computers \& Education, 72, 100-109.

https://doi.org/10.1016/j.compedu.2013.10.018

De la Flor, S., Ferrando, F., \& Fabregat-Sanjuan, A. (2016). Learning/training video clips: An efficient tool for improving learning outcomes in Mechanical Engineering. International Journal of Educational Technology in Higher Education, 13(1), 6. https://doi.org/10.1186/s41239-016-0011-4

Ebner, M., \& Holzinger, A. (2007). Successful implementation of user-centered game based learning in higher education: An example from civil engineering. Computers and Education, 49(3), 873-890. https://doi.org/10.1016/j.compedu.2005.11.026

Fabregat-Sanjuan, A. (2015a). 15-16 Laboratori De Tecnologia Mecànica (121479) Moodle Web Page. Moodle from Universitat Rovira i Virgili. Retrieved from: https://moodle.urv.cat/moodle/course/view.php?id=62827 (Last access date September 1st, 2015).

Fabregat-Sanjuan, A. (2015b). LabTecMec GEM URV YouTube channel. YouTube. Retrieved from: https://www.youtube.com/channel/UC9RGLBto22LOUnXODeALNtg (Last access date September 1st, 2015).

Fabregat-Sanjuan, A., Pàmies-Vilà, R., Ferrando Piera, F., \& De la Flor, S. (2016). Laboratori 3.0: Virtualització del laboratori amb una metodologia centrada en l'estudiant. Millora de l'assignatura de Laboratori de Tecnologia Mecànica mitjançant eines virtuals i una estratègia docent "blended learning." Revista CIDUI 2016, 11. Retrieved from: www.cidui.org/revistacidui

Fernández Rico, J.E., Fernández Fernández, S., Álvarez Suárez, A., \& Martínez Camblor, P. (2007). Éxito Académico y Satisfacción de los Estudiantes conlLa Enseñanza Universitaria. Relieve, 13(2), 203-214.

Galán Delgado, E., \& Cabrera Guillén, P. (2002). Factores contextuales y rendimiento académico. Revista electrónica interuniversitaria de formación del profesorado. Asociación Universitaria de Formación del Profesorado. $\quad$ Retrieved from: http://dialnet.unirioja.es/servlet/articulo? $\underline{\text { codigo }}=1034506 \&$ info $=$ resumen $\&$ idioma $=S P A$

Gámiz Sánchez, V., Montes Soldado, R., \& Pérez López, M. C. (2014). Self-assessment via a blended-learning strategy to improve performance in an accounting subject. RUSC. Universities and Knowledge Society Journal, 11(2), 43. https://doi.org/10.7238/rusc.v11i2.2055 
Garrison, D.R., \& Vaughan, N.D. (2007). Blended Learning in Higher Education. Blended Learning in Higher Education: Framework, Principles, and Guidelines. San Francisco, CA, USA: Jossey-Bass. https://doi.org/10.1002/9781118269558

Govindasamy, T. (2001). Successful implementation of e-learning: Pedagogical considerations. The Internet and Higher Education, 4(3), 287-299. https://doi.org/10.1016/S1096-7516(01)00071-9

Güzer, B., \& Caner, H. (2014). The Past, Present and Future of Blended Learning: An in Depth Analysis of Literature. Procedia - Social and Behavioral Sciences, 116, 4596-4603.

https://doi.org/10.1016/j.sbspro.2014.01.992

Kaur, M. (2013). Blended Learning - Its Challenges and Future. Procedia - Social and Behavioral Sciences, 93, 612-617. https://doi.org/10.1016/j.sbspro.2013.09.248

Kiili, K. (2005). Digital game-based learning: Towards an experiential gaming model. Internet and Higher Education, 8(1), 13-24. https://doi.org/10.1016/j.iheduc.2004.12.001

Liang, J. (2010). A blended web-based learning collaborative approach for a SEDM course in manufacturing engineering. In ASEE Annual Conference and Exposition, Conference Proceedings. Retrieved from: http://www.scopus.com/inward/record.url?eid=2-s2.0-77955956761\&partnerID=tZOtx3y1

Manca, S., \& Ranieri, M. (2013). Is it a tool suitable for learning? A critical review of the literature on Facebook as a technology-enhanced learning environment. Journal of Computer Assisted Learning, 29(July 2015), 487-504. https://doi.org/10.1111/jcal.12007

Osorio Gómez, L.A. (2010). Características de los ambientes híbridos de aprendizaje: Estudio de caso de un programa de posgrado de la Universidad de los Andes. Revista de Universidad Y Sociedad Del Conocimiento (RUSC), 7(1), 1-9. https://doi.org/10.7238/rusc.v7i1.655

Rama, C. (2014). University virtualisation in Latin America. RUSC Universities and Knowledge Society Journal, 11(3), 32-41. https://doi.org/10.7238/rusc.v11i3.1729

Sancho-Vinuesa, T., \& Escudero Viladoms, N. (2012). ¿Por qué una propuesta de evaluación formativa con feedback automático en una asignatura de matemáticas en línea? (Spanish). A Proposal for Formative Assessment with Automatic Feedback on an Online Mathematics Subject. (English). RUSC Universities and Knowledge Society Journal, 9(2), 59-260. https://doi.org/10.7238/rusc.v9i2.1285

Seluakumaran, K., Jusof, F.F., Ismail, R., \& Husain, R. (2011). Integrating an open-source course management system (Moodle) into the teaching of a first-year medical physiology course: A case study. Advances in Physiology Education, 35(4), 369-377. https://doi.org/10.1152/advan.00008.2011 
Sharples, M. (2000). The design of personal mobile technologies for lifelong learning. Computers \& Education, 34(3-4), 177-193. https://doi.org/10.1016/S0360-1315(99)00044-5

Smith, N.V. (2013). Face-to-face vs. Blended Learning: Effects on Secondary Students 'Perceptions and Performance. Procedia - Social and Behavioral Sciences, 89, 79-83. https://doi.org/10.1016/j.sbspro.2013.08.813

Snodin, N.S. (2013). The effects of blended learning with a CMS on the development of autonomous learning: A case study of different degrees of autonomy achieved by individual learners. Computers and Education, 61(1), 209-216. https://doi.org/10.1016/j.compedu.2012.10.004

Wang, A.I. (2015). The wear out effect of a game-based student response system. Computers and Education, 82, 217-227. https://doi.org/10.1016/j.compedu.2014.11.004

Welsh, E.T., Wanberg, C.R., Brown, K.G., \& Simmering, M.J. (2003). E-learning: Emerging uses, empirical results and future directions. International Journal of Training and Development, 7(4), 245-258. https://doi.org/10.1046/j.1360-3736.2003.00184.x

White, S. (2007). Critical success factors for e-learning and institutional change - Some organisational perspectives on campus-wide e-learning. British Journal of Educational Technology, 38(5), 840-850. https://doi.org/10.1111/j.1467-8535.2007.00760.x

Zhang, D., Zhou, L., Briggs, R.O., \& Nunamaker, J.F. (2006). Instructional video in e-learning: Assessing the impact of interactive video on learning effectiveness. Information and Management, 43(1), 15-27. https://doi.org/10.1016/j.im.2005.01.004

\section{Published by OmniaScience (www.omniascience.com) \\ Journal of Technology and Science Education, 2017 (www.jotse.org)}

Article's contents are provided on an Attribution-Non Commercial 3.0 Creative commons license. Readers are allowed to copy, distribute and communicate article's contents, provided the author's and JOTSE journal's names are included. It must not be used for commercial purposes. To see the complete licence contents, please visit http://creativecommons.org/licenses/by-nc/3.0/es/ 